\title{
Groundwater Quality Assessment of Parts of Owerri, Southeastern Nigeria
}

\author{
Ikechukwu B. Ijeh \\ (Department of Physics, Michael Okpara University of Agriculture, Umudike, PMB 7267, Umuahia, Abia State, \\ Nigeria.)
}

\begin{abstract}
Nineteen samples of groundwater were obtained from various boreholes in parts of Owerri, Southeastern Nigeria and subjected to physico-chemical analysis using standard laboratory techniques. The study was aimed at the assessment of the groundwater quality indicators namely: $\mathrm{pH}$, electrical conductivity $(\mathrm{N})$, phosphate $\left(\mathrm{PO}_{4}\right)$, sulphate $\left(\mathrm{SO}_{4}\right)$, nitrate $\left(\mathrm{NO}_{3}^{-}\right)$and total dissolved solids $(\mathrm{TDS})$. The result shows that electrical conductivity is above the WHO standard in the following areas: Girls' Secondary School, Owerri (BH39), Aladinma (BH41), Obube (BH42)), Amauzi Obowo (BH59), Model Primary School, Owerri (BH65), and Avu Amaaku (BH66). There are low pH values at Ugakwoche - Obube (BH42) and Umuakpaa - Obube (BH44) which indicates acidity. The rest of the areas have $p H$ values within the acceptable range of 6.5-8.5. The acidity of the Obube area probably results from carbonic acid derived from the solution of $\mathrm{CO}_{2}$ from both the atmosphere and the decomposition of plant materials in the soil zone. Acidic waters are typically low in buffering calcium minerals, but are high in dissolved carbon dioxide gas, which can cause the low pH or acidity. Calcite neutralizer tanks with natural crushed and screened pure calcium carbonate easily neutralize acidic water from 6.0 to 6.9. Below 6.0 a blend of calcite and Corosex is recommended. Common systems used to treat low pH include Calcite Neutralizer, calcite \& Corosex Blend Neutralizer, pflow Neutrilizer, Soda Ash Feed Pump Injection System.
\end{abstract}

Keywords: Acidity, Groundwater quality, Hydro-geochemical, Imo River Basin, Physico-chemical.

\section{Introduction}

Water is essential for livelihood as well as socio-economic development of any community. Many communities in Nigeria, especially in the Imo River Basin area rely on surface and groundwater for both domestic and agricultural water supplies. Groundwater pollution is a growing environmental problem, especially in developing countries. Many major cities and small towns in Nigeria depend on groundwater for water supplies, mainly because of its abundance, stable quality and also because it is inexpensive to exploit. However, the urbanization process threatens the groundwater quality because of the impact of domestic and industrial waste disposal. This results in aquifer deterioration, since some of these waste products, including sewage and cesspool may be discharged directly into the aquifer system. Water soluble wastes and other materials that are dumped, spilled or stored on the surface of the land or in sewage disposal pits can be dissolved by precipitation, irrigation waters or liquid wastes and eventually seep through the soil in the unsaturated zone to pollute the groundwater. Once contaminated, it is difficult, if not impossible, for the water quality to be restored. Thus constant monitoring of groundwater quality is needed so as to record any alteration in the quality and outbreak of health disorders. Groundwater quality depends, to some extent, on its chemical composition which may be modified by natural and anthropogenic sources [1]. Rapid urbanization, especially in developing countries like Nigeria, has affected the availability and quality of groundwater due to waste disposal practice, especially in urban areas. Once groundwater is contaminated, its quality cannot be restored by stopping the pollutants from source [2]. As groundwater has a huge potential to ensure future supply of water, it is important that human activities on the surface do not negatively affect the precious resource [3]. Poor environmental management creates havoc on the water supply and hygiene and undermines public health [4]. Tay and Kortatsi emphasize on the importance of groundwater globally as a source for human consumption and changes in quality with subsequent contamination can, undoubtedly, affect human health[5].

Acidified groundwater issues have been reported from many parts of the world particularly in North America and Europe [6][7][8]. Groundwater in most hard-rock aquifers are also known to be vulnerable to quality problems that may have serious impact on human health [9]. The rocks are often carbonate-deficient and give rise to poorly buffered groundwater (acidic groundwater) that encourage the dissolution of elements such as $\mathrm{Al}, \mathrm{Mn}, \mathrm{Be}$ and $\mathrm{Fe}$ from most minerals if they are present in the rock matrix into the groundwater and make the groundwater unsafe for drinking [10]. Acidity of groundwater can cause corrosion problems leading to high maintenance costs and shortened life of hand pumps and accessories. It can also lead to high metal concentrations in the borehole that may cause aesthetic problems and, in extreme cases, physiological problems. 


\subsection{Geology of the Study Area}

Owerri lies within the Coastal Plain sands of the Benin Formation. The Benin Formation ( Miocene to Recent) covers more than half of the area of the Imo River Basin. It consists of sands, sandstones, and gravels, with intercalations of clay and sandy clay. The sands are fine-medium-coarse grained and poorly sorted [11][12]. Petrographic study on several thin sections show that quartz makes up more than $95 \%$ of all grains, but Asseez and Avbovbo indicated a possible presence of more percentage of other skeletal materials including feldspar [13][14][15]. This formation has very low dip to the south and south-west. The youngest deposits in the basin are alluvium of Recent age found mainly at the estuary of the Imo River at the Atlantic Ocean and on the flood plains of the river.

The study area is drained by two rivers, namely: Otamiri and Nworie. The Otamiri river has a maximum average flow of $10.7 \mathrm{~m}^{3} / \mathrm{s}$ in the rainy season (September - October) and a minimum average flow of about $3.4 \mathrm{~m}^{3} / \mathrm{s}$ in the dry season (November - February). The total annual discharge of the Otamiri is about $1.7 \mathrm{x}$ $108 \mathrm{~m}^{3}$, and 22 percent of this $\left(3.74 \times 107 \mathrm{~m}^{3}\right)$ comes from direct runoff from rainwater and constitutes the safe yield of the river [12]. The depth to groundwater varies from $15 \mathrm{~m}-35 \mathrm{~m}$ in parts of the Owerri urban area. The aquifers have reasonable thickness and are extensive.

The study area (Fig. 1) is located around latitude $5^{\circ} 29^{\prime}$ and longitude $7^{\circ} 02^{\prime}$.

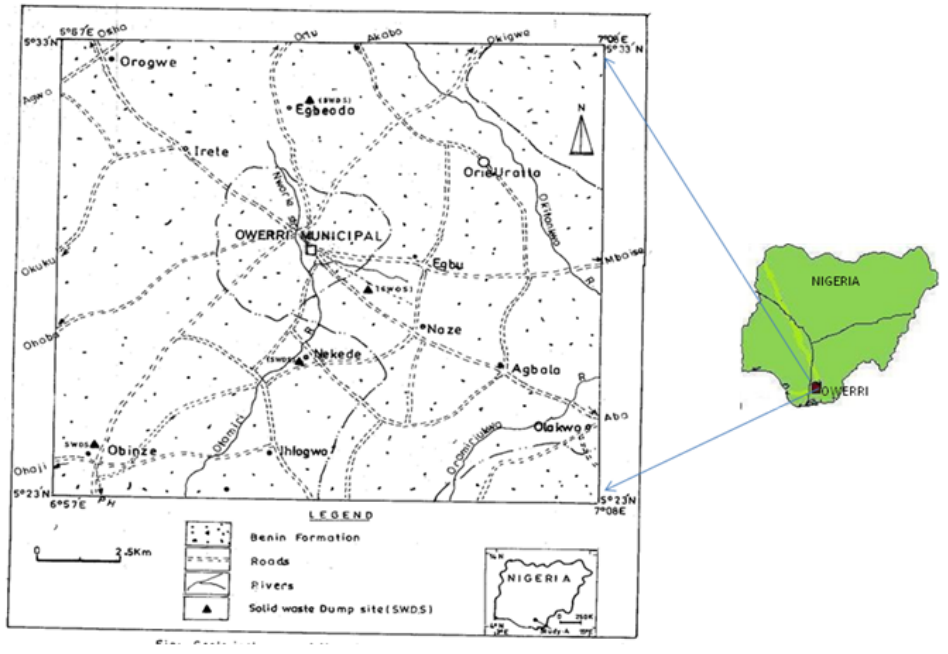

\section{Methodology}

Investigations of the pollution status of groundwater in the study area were conducted recently by collecting water samples from boreholes in different locations in the study area. Water samples from 19 randomly selected boreholes in the study area were analyzed for chemical quality at the UNICEF Water Project, Owerri, and Imo State Environmental Protection Agency, respectively. The result was geo-processed to obtain groundwater quality maps showing the spatial variation of $\mathrm{pH}$, electrical conductivity, sulphate, phosphate, total dissolved solids (TDS), salinity, nitrate respectively. The samples were stored in a sterilized $250 \mathrm{ml}$ bottles and then taken to the laboratory for analysis. The electrical conductivity, total dissolved solids, Nitrate, sulphate, phosphate and salinity were determined using a HA-CH 44600-00 Condutivity/TDS meter at a temperature of $20^{\circ} \mathrm{C}$. These samples were refrigerated and analyzed within 24 hours. All plastics and glass wares utilized were pre-washed with detergent water solution, rinsed with tap water and soaked for 48 hours in $50 \% \mathrm{HNO}_{3}$ then rinsed thoroughly with distilled- deionized water. They were then air-dried in a dust free environment. The $\mathrm{pH}$ was determined using a $\mathrm{HACH}$ sensor $3 \mathrm{pH}$ meter. The turbidity was determined using a spectrophotometer. The result is presented in Table 1. 
Table 1 : GROUNDWATER OUALITY DATA OF OWERR

\begin{tabular}{|c|c|c|c|c|c|c|c|c|c|c|c|c|}
\hline \multirow{2}{*}{$\begin{array}{l}\mathbf{S} / \\
\mathbf{N}\end{array}$} & \multirow{2}{*}{ 园 } & \multirow[t]{2}{*}{ LOCATION } & \multicolumn{2}{|c|}{$\begin{array}{l}\text { COORDINATE } \\
\text { S }\end{array}$} & \multirow[t]{2}{*}{$\begin{array}{l}\mathbf{p} \\
\mathbf{H}\end{array}$} & \multirow{2}{*}{ 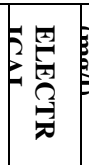 } & \multirow{2}{*}{ 记 } & \multirow{2}{*}{ 因恣 } & \multirow{2}{*}{$=$} & \multirow{2}{*}{ 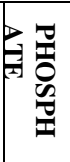 } & \multirow{2}{*}{ 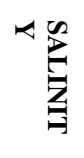 } & \multirow{2}{*}{ 氙 } \\
\hline & & & 5 & 恶齐 & & & & & & & & \\
\hline \multirow[t]{2}{*}{1} & $\mathrm{BH} 3$ & TIMBER & 7.0383 & 5.47317 & 6.5 & 21 & 36 & 13.50 & 2.0 & -- & 3.3 & -- \\
\hline & 6 & $\begin{array}{l}\text { SHADE } \\
\text { OWERRI }\end{array}$ & 6 & & & .1 & .5 & 0 & 0 & & & \\
\hline \multirow[t]{2}{*}{2} & $\mathrm{BH} 3$ & OWERRI & 7.0190 & 5.48557 & 7.0 & 111. & 58 & 1.30 & 0.8 & -- & 7.42 & -- \\
\hline & 9 & $\begin{array}{l}\text { GIRLS' SEC, } \\
\text { OWERRI }\end{array}$ & 4 & & & 3 & .7 & 0 & 0 & & & \\
\hline \multirow[t]{2}{*}{3} & $\mathrm{BH} 4$ & ALADINMA & 7.0420 & 5.48922 & 7.1 & 148.1 & 177 & 0.13 & 4.0 & -- & 2.48 & -- \\
\hline & 1 & OWERRI & 5 & & & & .7 & 0 & 0 & & & \\
\hline \multirow[t]{2}{*}{4} & $\mathrm{BH} 4$ & UGAKWOCH & 7.1423 & 5.41324 & 6.0 & 101. & 51 & 11.00 & 12. & -- & 1.68 & -- \\
\hline & 2 & $\begin{array}{l}\text { E OBUBE, } \\
\text { OWERRI }\end{array}$ & 2 & & & 0 & .0 & 0 & 5 & & & \\
\hline \multirow[t]{2}{*}{5} & $\mathrm{BH} 4$ & UMUCHOKU & 7.1427 & 5.4176 & 6.5 & 53 & 26 & 15.00 & 0.3 & -- & 0.75 & -- \\
\hline & 3 & $\begin{array}{l}\text { OBUBE, } \\
\text { OWERRI }\end{array}$ & 4 & 7 & & .0 & .5 & 0 & 0 & & & \\
\hline \multirow[t]{2}{*}{6} & $\mathrm{BH} 4$ & UMUAKPAA & 7.1545 & 5.41924 & 6.3 & 82 & 41 & 0.12 & 2.5 & -- & 1.16 & -- \\
\hline & 4 & $\begin{array}{l}\text { OBUBE, } \\
\text { OWERRI }\end{array}$ & 9 & & & .0 & .0 & 0 & 0 & & & \\
\hline \multirow[t]{2}{*}{7} & $\mathrm{BH} 4$ & VILLA & 7.0224 & 5.48933 & 6.9 & 49 & 25 & 0.00 & -- & -- & 4.95 & -- \\
\hline & 6 & $\begin{array}{l}\text { MARIA } \\
\text { OWERRI }\end{array}$ & 7 & & & .0 & .0 & 0 & & & & \\
\hline \multirow[t]{2}{*}{8} & $\mathrm{BH} 4$ & AKATA & 6.9317 & 5.47251 & 6.6 & -- & -- & -- & 6.00 & -- & 2.47 & 1. \\
\hline & 7 & $\begin{array}{l}\text { AMAPU, } \\
\text { OKUKU }\end{array}$ & 9 & & & & & & & & & $\mathbf{0}$ \\
\hline \multirow[t]{2}{*}{9} & $\mathrm{BH} 4$ & UMUGUMA & 6.9664 & 5.46144 & 7.0 & 16 & 8. & $32.80 c$ & 1.20 & -- & 2.50 & 0. \\
\hline & 8 & $\begin{array}{l}\text { AMAAKU, } \\
\text { OWERRI } \\
\text { WEST }\end{array}$ & 7 & & & .7 & 3 & & & & & 3 \\
\hline 1 & $\mathrm{BH} 4$ & UGORJI & 6.9246 & 5.48353 & 6.7 & 20 & 10 & 35.20 & 4.0 & -- & 6.60 & 2. \\
\hline $\mathbf{0}$ & 9 & $\begin{array}{l}\text { OWERRI } \\
\text { WEST }\end{array}$ & 1 & & & .8 & .5 & 0 & 0 & & & $\mathbf{0}$ \\
\hline 1 & BH5 & OBINZE & 6.9587 & 5.40472 & 6.8 & 36 & 18 & 39.60 & 3.0 & -- & 3.30 & 5.0 \\
\hline 1 & 0 & $\begin{array}{l}\text { BARACK } \\
\text { OWERRI } \\
\text { WEST }\end{array}$ & 4 & & & .5 & .0 & 0 & 0 & & & \\
\hline 1 & BH5 & OBINZE & 6.9582 & 5.41014 & 7.5 & 5. & 2. & 37.20 & 1.00 & -- & 2.50 & 10. \\
\hline 2 & 1 & MAMI MKT & 3 & & & 3 & 6 & 0 & & & & $\mathbf{0}$ \\
\hline 1 & BH5 & UZII & 7.0338 & 5.47851 & 7.2 & 66 & 33 & 50.600 & 0.01 & -- & 3.30 & 0.1 \\
\hline 3 & 2 & $\begin{array}{l}\text { PRIMARY } \\
\text { SCH. OWERRI }\end{array}$ & 4 & & & .6 & .3 & & & & & \\
\hline 1 & BH5 & IHIAGWA, & 7.0049 & 5.39764 & 7.5 & 44 & 2. & 2.40 & -- & -- & 2.50 & 13. \\
\hline 4 & 6 & $\begin{array}{l}\text { OWERRI } \\
\text { WEST }\end{array}$ & 4 & & & .0 & 0 & 0 & & & & $\mathbf{0}$ \\
\hline 1 & BH5 & FUTO, & 7.0121 & 5.40130 & 6.5 & 44 & 2. & 2.40 & -- & -- & 2.50 & 13. \\
\hline 5 & 7 & IHIAGWA & 2 & & & .0 & 0 & 0 & & & & $\mathbf{0}$ \\
\hline 1 & BH5 & AMAUZI, & 7.3215 & 5.57432 & 7.6 & 153. & -- & 0.03 & 0.02 & -- & -- & -- \\
\hline 6 & 9 & OBOWO & 3 & & & 0 & & 0 & & & & \\
\hline 1 & BH6 & MGBOMA & 7.1470 & 5.43726 & 6.8 & 64 & 32 & 25.00 & -- & 0.4 & 3.30 & -- \\
\hline 7 & 0 & $\begin{array}{l}\text { OBUBE } \\
\text { OWERRI }\end{array}$ & 1 & & & .2 & .1 & 0 & & 5 & & \\
\hline 1 & BH6 & MODEL PRI. & 7.0224 & 5.48933 & 7.3 & 135. & 67 & 13.20 & 0.0 & -- & 2.13 & $\mathbf{0}$ \\
\hline 8 & 5 & $\begin{array}{l}\text { SCH., } \\
\text { OWERRI }\end{array}$ & 7 & & & 5 & .9 & 0 & 0 & & & \\
\hline 1 & BH6 & $\overline{A V U}$ & 6.9616 & 5.44602 & 7.5 & 13 & 69 & 11.00 & -- & 0.3 & 33.0 & -- \\
\hline 9 & 6 & AMAAKU & 2 & & & 6 & .0 & $\mathbf{0}$ & & 3 & $\mathbf{0}$ & \\
\hline
\end{tabular}




\section{Results And Discussion}

The specific parameter maps of groundwater quality indicators were developed to facilitate the rapid assessment of the extent of pollution of the various locations within the study area in terms of their respective concentrations. Contour maps of the spatial variation of $\mathrm{pH}$, electrical conductivity, phosphate, sulphate, salinity, total dissolved solid, nitrate, and turbity were also developed [16].

\section{$3.1 \mathrm{pH}$}

Fig. 2 shows the map of the spatial variation of $\mathrm{pH}$ in the study area. The result shows that much of the study area have $\mathrm{pH}$ values within the acceptable WHO standard, except Ugokwoche Obube (BH 42) and Umuakpaa Obube (BH44) where the $\mathrm{pH}$ is lower than 6.5. This indicates that the groundwater in this area is acidic.The acidity probably results from carbonic acid derived from the solution of $\mathrm{CO}_{2}$ from both the atmosphere and the decomposition of plant materials in the soil zone. The acidity of the groundwater gives slight sour taste to drinking water and has also led to the mobilization of trace metals particularly iron, manganese, aluminium and arsenic into the groundwater system, because of the corrosive effect of acidic water. It is the amount and type of dissolved minerals that give the groundwater its distinctive taste. Since borehole supply is rarely treated, these trace metals end up in domestic supplies resulting in health implications and complaints. Acidic waters are typically low in buffering calcium minerals, but are high in dissolved carbon dioxide gas, which can cause the low $\mathrm{pH}$ or acidity.

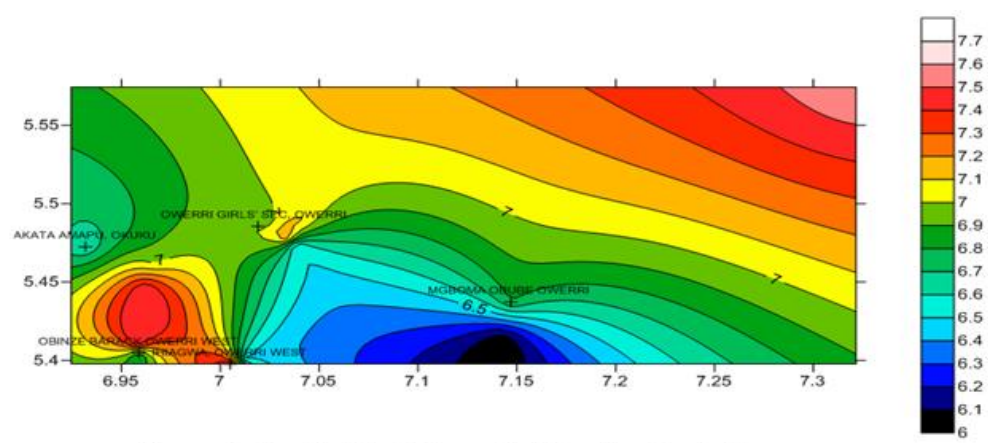

Figure 2: Spatial Variation of $\mathrm{pH}$ in the Study Area

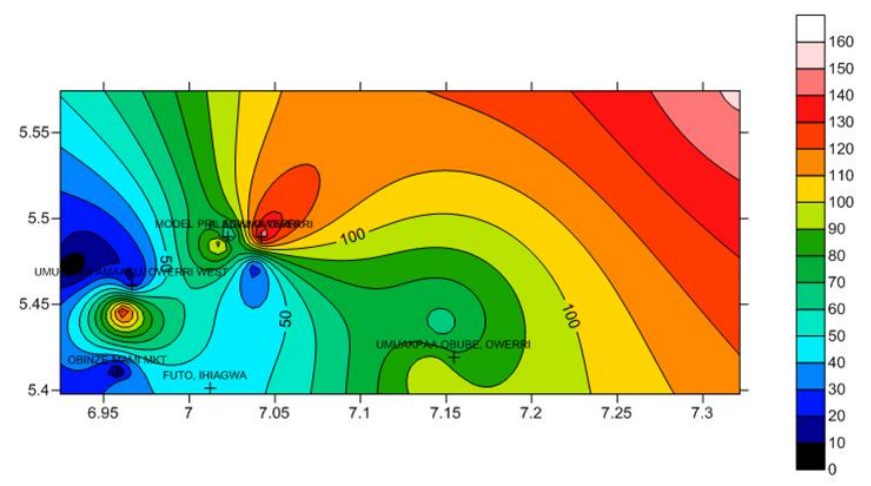

Figure 3: Spatial Variation of Electrical Conductivity in the Study Area

\subsection{Electrical Conductivity}

The map of the spatial variation of electrical conductivity is shown in Fig. 3. Electrical conductivity of water is used as an indicator of how salt- free, ion-free, or impurity-free the sample is; the purer the water the lower the conductivity (the higher the resitivity). The World Health Organization standard for acceptable electrical conductivity is $100 \mu \mathrm{s} / \mathrm{cm}$. Pure water has an electrical conductivity of $5.5 \mu \mathrm{s} / \mathrm{cm}$, which is a measure of the total dissolved solid (TDS), while rain water and ocean water have 5000 to $30000 \mu \mathrm{s} / \mathrm{cm}$ and 45,000 to $60,000 \mu \mathrm{s} / \mathrm{cm}$ respectively. Normal groundwater has a range of 100 to $2000 \mu \mathrm{s} / \mathrm{cm}$ [17]. The values electrical conductivity is above the WHO standard in the following areas: Girls' Secondary School, Owerri (BH39), Aladinma (BH41), Obube (BH42)), Amauzi Obowo (BH59), Model Primary School, Owerri (BH65), and Avu Amaaku (BH66). 


\subsection{Phosphate}

Fig. 4 shows the map of phosphate concentration in the study area. Phosphorus is one of the key elements necessary for the growth of plants and animals. Phosphates are not toxic to people or animals unless they are present in very high levels. Digestive problems could occur from extremely high levels of phosphate. The WHO standard for phosphate in drinking water is $5 \mathrm{mg} / 1$. All locations within the study area have generally low concentration of phosphate $(\leq 2 \mathrm{mg} / \mathrm{l})$.

\subsection{Nitrate}

Fig. 5 shows the map of spatial variation of nitrate concentration in the study area. Nitrate is an essential ingredient of plant nutrition. It is, however regarded as an indicator of pollution in public water supply [18]. The WHO standard for nitrate in drinking water is $50 \mathrm{mg} / \mathrm{l}$. This standard is not exceeded in any part of the study area.

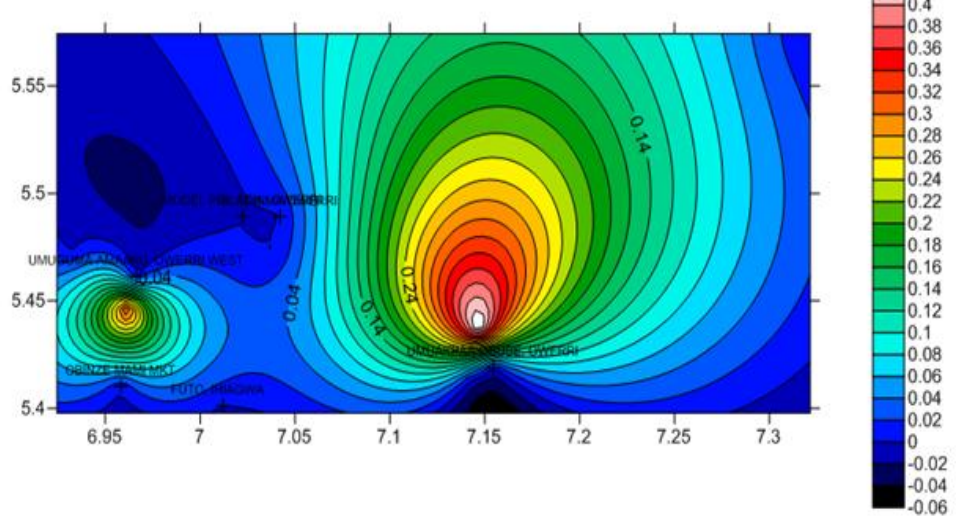

Figure 4: Spatial Variation of Phosphate in the Study Area

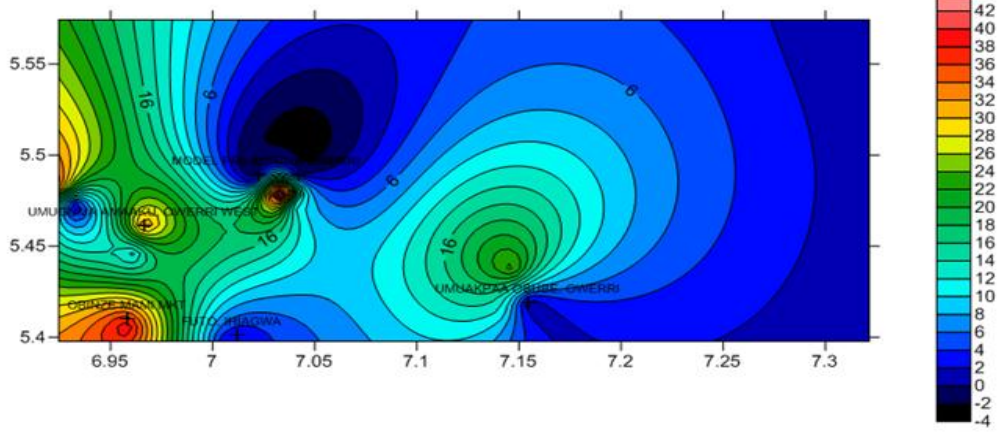

Figure 5: Spatial Variation of Nitrate in the Study Area

\subsection{Sulphate}

Fig. 6 shows the map of the spatial variation of sulphate concentration in the study area. Sulphate occurs mostly as Calcium Sulphate (Gypsum). Sodium and Magnesium Sulphate are readily soluble in water while Calcium Sulphate is less so. Sulphur is useful to plants. High levels of sulphate in drinking water can cause diarrhea. The WHO standard for Sulphate in drinking water is $250 \mathrm{mg} / 1$. From the study no borehole was found to have excessive sulphate.

\subsection{Total Dissolved Solids}

Fig. 7 shows the map of the spatial variation of the total dissolved solids (TDS) in the study area. The total dissolved solids (TDS) provides a rough indication of the overall suitability of water for whatever purpose. The WHO standard for TDS in drinking water is $250 \mathrm{mg} / \mathrm{l}$. No borehole location exceeded the required maximum standard. 


\subsection{Salinity}

Fig. 8 shows the map of spatial variation of salinity in the study area. The salinity indicates the presence of sodium chloride in the sample. It is generally soluble and essential to animals and man. However, in higher concentrations it inhibits plant growth, and can be harmful to man. The WHO standard for salinity of drinking water is $50 \mathrm{mg} / \mathrm{l}$. No location in the study area exceeded the WHO standard.

\subsection{Turbidity}

Fig. 9 shows the map of the turbidity in the study area. Turbidity is the amount of cloudiness in the water. This can vary from a river full of mud and silt where it would be impossible to see through the water (high turbidity), to a spring water which appears to be completely clear (low turbidity).Turbidity can be caused by silt, sand and mud, bacteria and other germs, and chemical precipitates. It is very important to measure the turbidity of domestic water supplies, as these supplies often undergo some type of water treatment which can be affected by turbidity. Turbidity was measured in nephelometric turbidity units (NTU), using a turbidity meter because of its accuracy. The map shows that most of the areas investigated are within acceptable WHO standard.

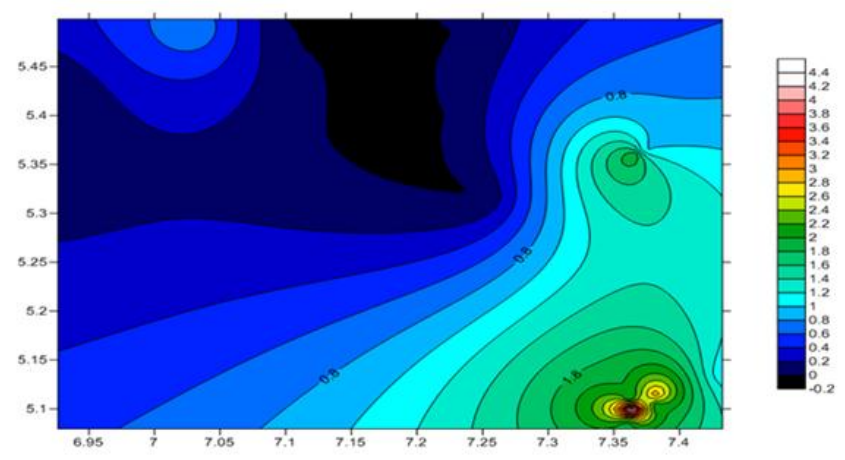

Figure 6: Spatial Variation of Nitrate in the Study Area

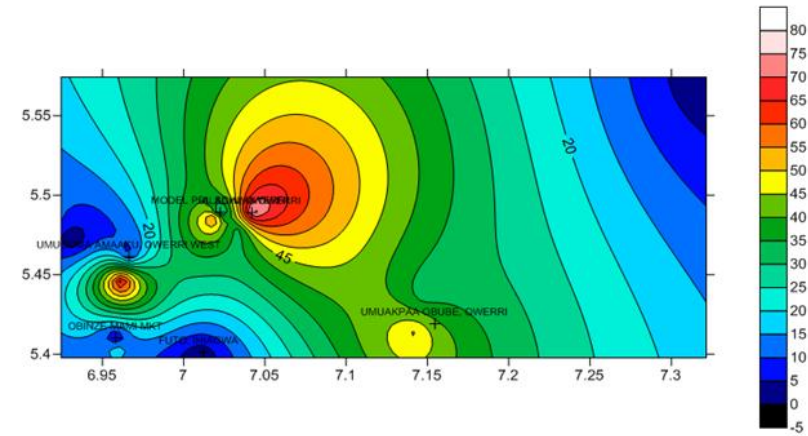

Figure 7: Spatial Variation of Total Dissolved Solid in the Study Area

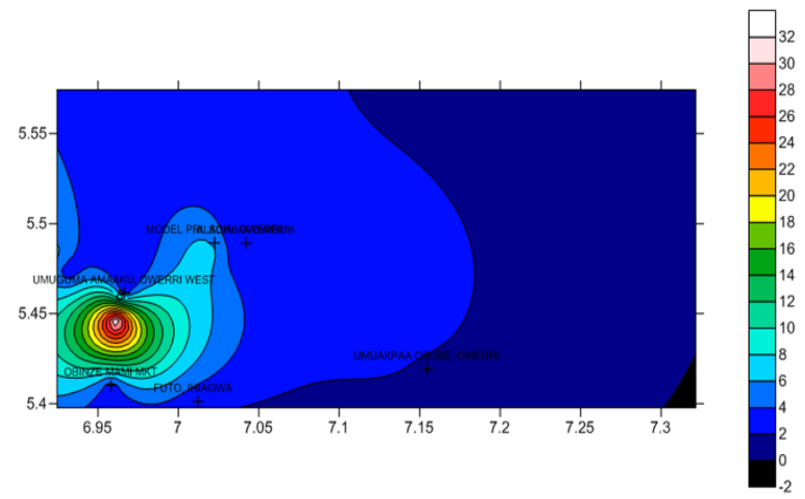

Figure 8: Spatial Variation of Salinity in the Study Area 


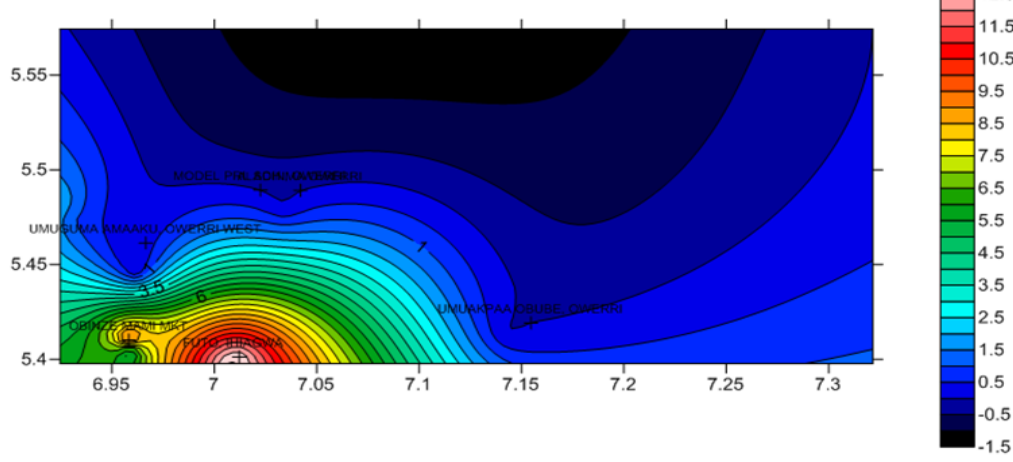

Figure 9: Spatial Variation of Turbidity in the Study Area

\section{Conclusion}

From the groundwater quality analysis, electrical conductivity is above the WHO standard in the following areas: Girls' Secondary School, Owerri (BH39), Aladinma (BH41), Obube (BH42)), Amauzi Obowo (BH59), Model Primary School, Owerri (BH65), and Avu Amaaku (BH66). There are low pH values at Ugakwoche - Obube (BH42) and Umuakpaa - Obube (BH44) which indicates acidity. The rest of the areas have $\mathrm{pH}$ values within the acceptable range of 6.5-8.5. The acidity of the Obube area probably results from carbonic acid derived from the solution of $\mathrm{CO}_{2}$ from both the atmosphere and the decomposition of plant materials in the soil zone. Virtually all groundwater comes from precipitation that soaks into the soil and passes down to the aquifer. Rainwater has a slightly acidic $\mathrm{pH}$, therefore it tends to dissolve solid minerals in the soil and in the aquifer. Different rocks, e.g., sandstone, limestone and basalt all have different minerals and therefore, groundwater in contact with these materials will have different compositions. Acidic waters are typically low in buffering calcium minerals, but are high in dissolved carbon dioxide gas, which can cause the low $\mathrm{pH}$ or acidity. Calcite neutralizer tanks with natural, crushed and screened pure calcium carbonate easily neutralize acidic water from 6.0 to 6.9. Below 6.0 a blend of calcite and Corosex is recommended. Calcite is a crushed and screened white marble media, which can be used to neutralize acidic or low $\mathrm{pH}$ waters to a neutral, less corrosive effluent. Corosex is a specially processed hard, bead like magnesia, adapted for use in filters to neutralize acidity by increasing the $\mathrm{pH}$. Common systems used to treat low pH include Calcite Neutralizer, calcite and Corosex Blend Neutralizer, Soda Ash Feed Pump Injection System[19]. In neutralizer filters, acidic waters slowly dissolve the calcium and magnesium media on contact as the water flows through the filter, raising the $\mathrm{pH}$ of the water and increasing the alkalinity. This eliminates the effects of corrosive water chemistries and can help to prevent corrosion of piping and fixtures. Generally the lower the $\mathrm{pH}$, the lower the hardness and alkalinity, and the higher the total dissolved solids will mean the water is more corrosive. Further studies can be undertaken to determine the amount and type of trace minerals present in the groundwater.

\section{Acknowledgements}

The authors are grateful to the Imo State Rural Water Supply Agency, and UNICEF Owerri for giving me access to their information resources. Special thanks to Dr. Alex Opara of Federal University of Technology Owerri for his useful contributions in the work.

\section{References}

[1] A.S.T. Wadie and Abuljalil G.A.S., Assessment of hydrochemical quality of groundwater under some urban areas with Sana'a $\begin{array}{llll}\text { Secretariat. } & \text { Ecletica } & \text { quimica, } & \text { 3ww.SCIELO.BR/EQ. }\end{array}$ C. R. Ramakrishnaiah, C. Sadashivaiah, and G. Ranganna, Assessment of Water Quality Index for the Groundwater in Tumkur Taluk, Karnataka State, India. E-Journal of Chemistry. 6(2). 2009, 523-530.

[2] P. R. Sarukkalige, Impact of land use on groundwater quality in Western Australia: Improving integrated surface and groundwater resources management in a vulnerable and changing world, Proc. of Joint International Association of Hydrological Scientists (IAHS) and International Association of Hydrogeologists (IAH) Convention, Hyderabad, India, IAHS Publ., 2009, $136-142$.

[3] E.I. Okoro, B.C.E. Egboka, O.L. Anike and A.G. Onwuemesi , Integrated water resources management of the Idemili River and Odo River Drainage Basins, Nigeria: Improving integrated surface and groundwater resources management in a vulnerable and changing world, Proc. of Joint International Association of Hydrological Scientists (IAHS) and International Association of Hydrogeologists (IAH) Convention, Hyderabad, India, IAHS Publ. 2009, 117-122.

[4] C. Tay and B. Kortatsi, Groundwater quality studies: A Case study of the Densu Basin, Ghana. West African Journal of Applied Ecology, 12 (1), 2008.

[5] H. Hultberg and A. Wenbald, Acid groundwaters in Southwestern Sweden, in D. Drablos and A. Tollan (Ed.), Ecological Impact of Acid Precipitation, International Conference, Sandefjord, Norway, 1980, 220-221.

[6] C.A.J. Appelo, G.J.W. Krajenbrank, C.C.D.F. van Ree and L. Vasak, Controls on groundwater quality in the NW Veluwe Catchment. Soil Protection Series 11, Staatsuitgeveriji, Den hag, 1982, 140. 
[7] A. Grivall, C. S. Cole, B. Allard and P. Sanden, Quality trends of public water supplies in Sweden. Acid Precipitation and Human Health-Part 1. Water Quality Bulletin 11(1), 1986, 6-11 and 58.

[8] P. L. Smedley, W.M. Ednunds, J. M. West, S. J. Gardner and K. B. Pelig-Ba, Vulnerability of shallow groundwater quality due to natural geochemical environment: Health problems related to groundwater in the Obuasi and Bologatanga Areas, Ghana, Report prepared for ODA under ODA/BGS Technology Development and research Programme, Project 92/5,1995.

[9] B. K. Kortatsi, Acidification of groundwater and its implications on rural water supply in the Ankobra Basin, Ghana. West African Journal of Applied Ecology, 4(1), 2003, 35-47.

[10] A.Whiteman, Nigeria: Its Petroleum Geology Resources and Potentials, Graham and Trotman Publ., London SWIVIDE, 2(1), 1982.

[11] K. O. Uma and B. C. E. Egboka, Groundwater potentials of Owerri and its environs. Nig. Journal of Min. Geol., 22(1), 1985, $57-$ 64.

[12] A. C. Onyeagocha, Petrography and depositional environment of the Benin Formation. Nigerian. Journal of Mining and Geology. 17(1), 1980, 147-151.

[13] L. O. Asseez, Review of the Stratigraphy, Sedimentation and Structure of the Niger Delta. In: of Nigeria. Elizabethan Publ. Co. Lagos, Nigeria, 1976.

[14] A. A. Avbovbo, (1978); Tertiary Lithostratigraphy of Niger Delta Bull. Am. Assoc. Pet. Geol.,6(1), 1978, 295-306.

C.A. Kogbe (ed.) Geology

[15] B. I. Ijeh, Assessment of Pollution Status and Vulnerability of Water Supply Aquifers in Parts of Imo River Basin, Southeastern Nigeria, doctoral diss., Federal University of Techology Owerri, Nigeria, 2010, 121-142.

[16] World Health Organization (WHO), Guidelines for Drinking Water, 2011

[17] M.E. Offodile, (2002); Ground Water Study and Development in Nigeria (Mecon Geology and Eng. Services Ltd. 2002, 303-332.

[18] Clean Water Systems and Stores, www.cleanwaterstore.com/how-to-acid-water.html. 